INTERNATIONAL JOURNAL OF MULTidisciplinARY RESEARCH AND ANALYSis

ISSN(print): 2643-9840, ISSN(online): 2643-9875

Volume 05 Issue 01 January 2022

DOI: 10.47191/ijmra/v5-i1-29, Impact Factor: 6.072

Page No.- 236-243

\title{
Validity of Student Worksheet in Chapter Dynamic Electricity Based on Virtual Laboratory
}

\author{
Muhammad Habibbulloh ${ }^{1}$, Silvi Rosiva Rosdiana ${ }^{2}$, Agus Santoso ${ }^{3}$, Khoiro Mahbubah ${ }^{4}$ \\ ${ }^{1}$ Science Education, Faculty of Mathematics and Natural Science, State University of Surabaya, Indonesia \\ 2,3,4 Science Education, Faculty of Teacher Trainer and Education, Islamic University of Lamongan, Indonesia
}

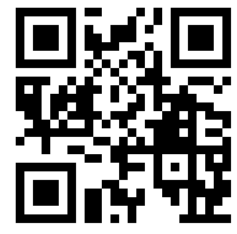

ABSTRACT: This study aims to determine the validity of student worksheet for Junior High School (JHS) in chapter dynamic electricity based on virtual laboratory as a companion for science learning during the Covid-19 pandemic in Indonesia. Worksheet is designed to enhance the critical thinking skills of students. It is validated by 3 expert validators from 3 leading universities in Indonesia. The instrument used to assess the format, language, content, and effectiveness of student worksheets in an effort to improve students' critical thinking skills. The data analysed by descriptive and quantitative. The results of the expert validator's assessment showed that the percentage of agreement of the student worksheet in the Format, Language and Content category also critical thinking assessment was "Valid". These means that student worksheet in chapter dynamic electricity based on virtual laboratory can be used with minor revision. The level of originality of the student worksheet is very high with parameter no penalty (NP). The conclusion from the research, the dynamic electricity worksheets developed have a high percentage of agreement and originality so that they can be used to accompany science learning during the pandemic to enhance students' critical thinking skills.

KEYWORDS: Student Worksheet, Dynamic Electricity, Virtual Laboratory

\section{INTRODUCTION}

The results of a survey conducted by the research team found that in schools in Indonesia, learning has been carried out online during covid-19 pandemic. asked on the research team's observations, this raises new problems in students' mastery of the material through online learning so that it requires new breakthroughs in these problems (Rhim, Hye Chang \& Han, Heeyoung, 2020), (Barry, C. \& Gerstman, J., 2015), (Martin, Florence \& Polly, Drew \& Ritzhaupt, Albert, 2020). In science learning material, the concept of dynamic electricity, many students do not understand the concepts explained by the teacher online. One of the factors that causes students to not understand the concept is that they cannot carry out a dynamic electricity practicum directly in a pandemic situation. This is also reinforced by the results of the online dynamic electricity quiz assessment where the average value of junior high school students on dynamic electricity material is below the minimum standard. Based on these facts, the research team developed a draft of dynamic electricity worksheets based on virtual laboratories.

Researchers think with the help of this worksheet, the teaching and learning process will be assisted and the critical thinking skills of junior high school students will improve even in the midst of limited circumstances. The virtual laboratory chosen is PhET (Physics Education Technology), which is one of the virtual laboratories developed by the University of Colorado Boulder. PhET is a virtual laboratory that contains learning simulations of physics, biology, and chemistry for classroom teaching or individual learning. PhET simulations emphasize the relationship between real-life phenomena and the underlying science, support interactive and constructivist approaches, provide feedback, and provide a creative workplace (Finkelstein, N., W. adams, C. Keller, K. Perkins \& C. Wieman, 2006). Based on several studies that refer to the PhET virtual laboratory, including the results of Sugiyono's research (2011) on the use of PhET, the conclusion is that the teaching and learning process using physics learning tools developed with the help of PhET multimedia and simple KIT for high school in the subject of optical tools is effective, where when the activities take place student activities are dominated by activities characterized by process skills and cooperative learning. It also strengthened by the results of research by Cicyn (2019). The other results of study concluded that learning using the PhET virtual laboratory could improve students' conceptual understanding (Athaillah, Ibn Khaldun, Mursal, 2017). The results of research concluded that the PhET Simulation contains learning materials for physics, biology and chemistry. 


\section{Validity of Student Worksheet in Chapter Dynamic Electricity Based on Virtual Laboratory}

PhET makes it easier for teachers and students in the learning process, so that it can foster motivation for students and increase student understanding of concepts (Khairunnisak, 2018). PhET simulation is appropriate to be applied in schools that do not have laboratory facilities so that they can help teachers in teaching. The results of other research state that learning using PhET simulations can provide more benefits than disadvantages, learning using PhET simulations not only provides alternative activities but can replace various activities in the physics laboratory but can also increase the ability of students to achieve learning outcomes (Fencl, J., 2013). In another research also concluded that the use of the PhET virtual lab had a positive effect on students' conceptual mastery of the photoelectric effect material (Habibbulloh M., 2019).

\section{METHOD}

The scheme of developing student worksheet follows the 4D model developed by Thiagarajan (Thiagarajan S, Semmel DS, dan Semmel MI, 1974) consist of 4 steps: define, design, develop, and disseminate. In the define phase, a concept and needs analysis is carried out in the learning process. Then entering the design phase, a virtual laboratory-based dynamic electrical worksheet was compiled to improve critical thinking skills, hereinafter referred to as draft 1 . In this phase, expert validation was carried out. The validation results and input obtained are then used to perfect draft 1 so that limited trials can be carried out. the results of the limited trial were then reformulated to improve the existing draft. then draft 1 enters the develop phase, namely developing draft 1 and completing the draft based on the results of limited testing, validation, and input from experts. the results of the develop phase become draft 2. the next phase is disseminated, which draft 2 is well packaged so that it is feasible to be distributed and used in the online science learning process.

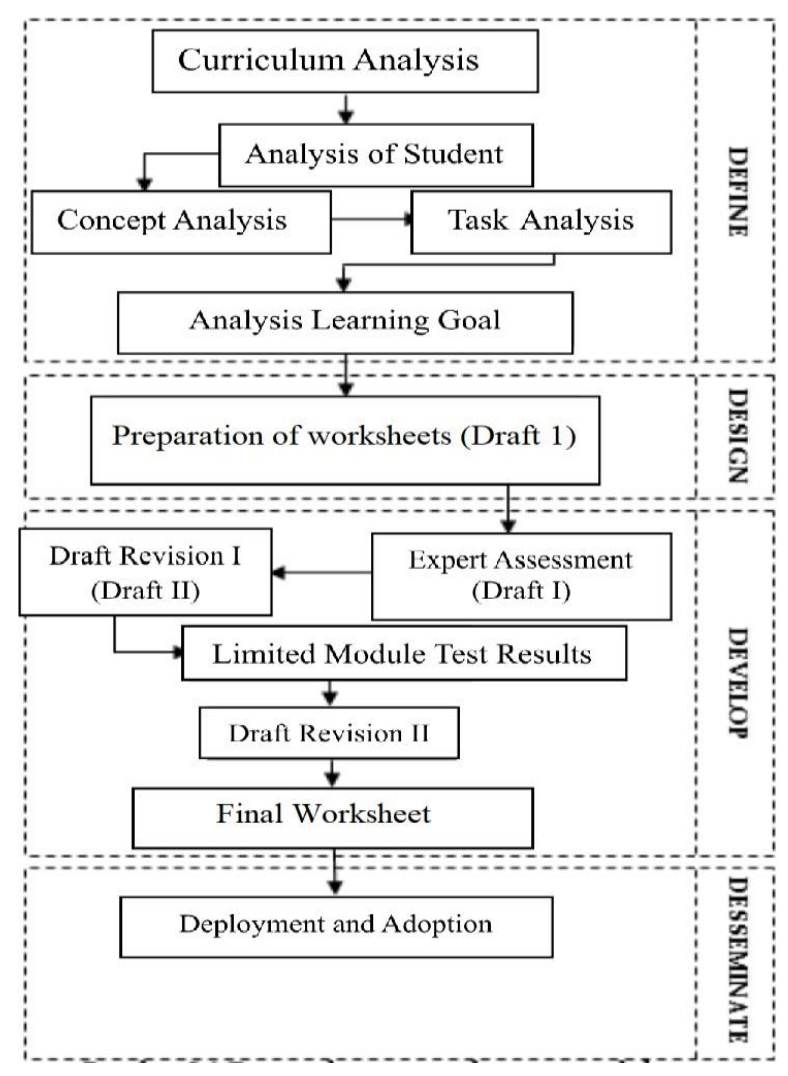

Figure 1. Thiagarajan 4-D Development Model Diagram

After draft of Student Worksheet in Chapter Dynamic Electricity Based on Virtual Laboratory has been formed (phase design) the research team made an assessment / validation instrument from the worksheets which included validation of format, language and content as well as validation of critical thinking skills taught in the worksheets including reasoning indicators, hypothesis testing, argumentation analysis, Likelihood and uncertainty analysis, and indicators of solving problems and making decisions. These are in accordance with the indicators of critical thinking proposed by Halpern (2014). Furthermore, the validation and adjustment of the validation results of the Dynamic Electrical Worksheet based on the Virtual Laboratory were carried out and adjusted. The result of validity data was analyzed using quantitative descriptive by calculating average value given by validator. The criteria interpreted according to table 1 adapted from Ratumanan and Laurens (2011). 
Validity of Student Worksheet in Chapter Dynamic Electricity Based on Virtual Laboratory

Table 1. Criteria of Score Interval

\begin{tabular}{|l|l|l|}
\hline Score Interval & Category & Description \\
\hline $3.60 \leq \mathrm{V} \geq 4.00$ & Very Valid & Can be used without revision \\
\hline $2.60 \leq \mathrm{V} \geq 3.59$ & Valid & Can be used with minor revision \\
\hline $1.60 \leq \mathrm{V} \geq 2.59$ & Less Valid & Can be used with major revision \\
\hline $1.00 \leq \mathrm{V} \geq 1.59$ & Invalid & Not yet in use and requires consultation \\
\hline
\end{tabular}

The aspects assessed in the virtual laboratory-based dynamic electrical worksheets expert validation with adaptation are as follows (Ratumanan, G.T. \& Laurens, T., 2011):

Table 2. Aspects assessed in general (Format, Language and Content)

\begin{tabular}{|c|c|}
\hline Rated Aspect & Indicators \\
\hline Format & $\begin{array}{l}\text { 1. Clarity of material distribution } \\
\text { 2. Have charm } \\
\text { 3. The numbering system is clear } \\
\text { 4. Room / layout arrangement } \\
\text { 5. Type and font size accordingly } \\
\text { 6. Suitability of the physical size of the worksheets with students }\end{array}$ \\
\hline Language & $\begin{array}{l}\text { 1. Grammatical correctness } \\
\text { 2. Suitability of sentences with the level of thinking and reading } \\
\text { ability and age of students } \\
\text { 3. Encourage interest in work } \\
\text { 4. Simplicity of sentence structure } \\
\text { 5. The sentence does not have a double meaning } \\
\text { 6. Clarity of instructions } \\
\text { 7. The communicative nature of the language used }\end{array}$ \\
\hline Content & $\begin{array}{l}\text { 1. The truth of the content / material } \\
\text { 2. It's an essential material } \\
\text { 3. Grouped in logical sections } \\
\text { 4. Practicing critical thinking skills according to the Halpern indicator } \\
\text { 5. Suitability of the task with the order of the material } \\
\text { 6. It be able to encourage students to find concepts } \\
\text { 7. Feasibility as a learning tool }\end{array}$ \\
\hline
\end{tabular}

The following aspects are assessed based on the criterion of critical thinking indicators according to Halpern with adaptation (Tiruneh, 2016):

Table 3. Critical thinking indicator criteria according to Halpern with adaptation

\begin{tabular}{|l|l|}
\hline Rated Aspect & Indicators \\
\hline Reasoning & $\begin{array}{l}\text { 1. Evaluating the validity of the data } \\
\text { 2. Interpret experimental results }\end{array}$ \\
\hline Hypothesis testing & $\begin{array}{l}\text { 1. Interpret the relationship between variables. } \\
\text { 2. Knowing the need for more information in making conclusions. }\end{array}$ \\
\hline Argument analysis & $\begin{array}{l}\text { 1. Identify important parts of the argument } \\
\text { 2. Summarize the appropriate statement from the data obtained }\end{array}$ \\
\hline $\begin{array}{l}\text { Likelihood and uncertainty analysis } \\
\text { making }\end{array}$ & $\begin{array}{l}\text { 1. Use possible judgments to make decisions } \\
\text { 2. Understand the information that may be in decision making }\end{array}$ \\
\hline
\end{tabular}




\section{Validity of Student Worksheet in Chapter Dynamic Electricity Based on Virtual Laboratory}

The valuation agreement is calculated based on similarity of values given by experts with the formula (Ibrahim,2005), (Hayes, John \& Hatch, Jill. 1999), (Lewin, Lewis \& Wakefield, James. (1979):

$$
R=\left(1-\frac{A-B}{A+B}\right) \times 100 \%
$$

Descriptions:

$R=$ Percentage of Agreement

$A=$ the aspect frequency which gives the high frequency

$B=$ the aspect frequency which gives the low frequency

the lower limit of the reliability coefficient / percentage of agreement for a good performance or observation is more than 0.7 or 70\% (Linn, 2020).

Furthermore, to determine the originality of the work created, the virtual laboratory-based dynamic electrical worksheets that have been created and validated are tested with Turnitin (Villar-Mayuntupa, 2020), (Sinaga, 2018), (Li Jinrong, 2018). The following is scheme for different similarity index by Turnitin (Halgamuge, 2017):

Table 4. Penalty scheme for different similarity index

\begin{tabular}{|l|l|l|}
\hline Parameter & Notation & Value \\
\hline Similarity index (Si) for maximum penalty & Pmax & $75-100 \%$ \\
\hline Similarity index (Si) for average penalty & Pavg & $50-74 \%$ \\
\hline Similarity index (Si) for minimum penalty & Pmin & $25-49 \%$ \\
\hline Similarity index (Si) for no penalty & NP & $0-24 \%$ \\
\hline Exclusion of consecutive word count (consecutive words) & CW & 3 \\
\hline
\end{tabular}

\section{RESULT AND DISCUSSION}

The data result of this research including: (1) validation from experts about the virtual laboratory-based Dynamic Electricity Worksheets, (2) originality of creation using Turnitin. Percentage of agreement (PA) is obtained based on the level of compatibility of the value between expert validators (Ibrahim, 2005). The following are the results of the expert validator's assessment:

Table 5. Expert Validator Result Value Tabulation for General Indicators

\begin{tabular}{|c|c|c|c|c|}
\hline & General Indicators & $V_{1}$ & $V_{2}$ & $V_{3}$ \\
\hline \multicolumn{5}{|c|}{ Format } \\
\hline 1 & Clarity of material distribution & 3 & 4 & 4 \\
\hline 2 & Interesting for student & 4 & 4 & 3 \\
\hline 3 & The numbering system is clear & 4 & 3 & 3 \\
\hline 4 & Room / layout arrangement & 3 & 3 & 4 \\
\hline 5 & Type and font size accordingly & 3 & 4 & 4 \\
\hline 6 & Suitability of the physical size of the worksheets with students & 4 & 3 & 4 \\
\hline \multicolumn{5}{|c|}{ Language } \\
\hline 1 & Grammatical correctness & 3 & 4 & 3 \\
\hline 2 & Suitability of sentences with the level of thinking and reading ability and age of students & 4 & 3 & 3 \\
\hline 3 & Encourage interest in work & 4 & 4 & 4 \\
\hline 4 & Simplicity of sentence structure & 4 & 4 & 3 \\
\hline 5 & The sentence does not have a double meaning & 3 & 4 & 4 \\
\hline 6 & Clarity of instructions & 3 & 4 & 4 \\
\hline 7 & The communicative nature of the language used & 3 & 4 & 3 \\
\hline \multicolumn{5}{|c|}{ Content } \\
\hline 1 & The truth of the content / material & 4 & 4 & 4 \\
\hline 2 & It's an essential material & 4 & 4 & 4 \\
\hline
\end{tabular}


Validity of Student Worksheet in Chapter Dynamic Electricity Based on Virtual Laboratory

\begin{tabular}{|c|c|c|c|c|}
\hline & General Indicators & $\mathbf{V}_{1}$ & $\mathbf{V}_{\mathbf{2}}$ & $\mathbf{V}_{\mathbf{3}}$ \\
\hline 3 & Grouped in logical sections & 3 & 4 & 4 \\
\hline 4 & Practicing critical thinking skills according to the Halpern indicator & 3 & 4 & 4 \\
\hline 5 & Suitability of the task with the order of the material & 4 & 4 & 4 \\
\hline 6 & It is able to encourage students to find concepts & 3 & 4 & 3 \\
\hline 7 & Feasibility as a learning tool & 4 & 4 & 4 \\
\hline
\end{tabular}

Table 6. Expert Validator Result Value Tabulation for Critical Thinking Skill's Indicators

\begin{tabular}{|c|c|c|c|c|}
\hline & Indicators of Critical Thinking Skill & $\mathbf{V}_{1}$ & $\mathbf{V}_{2}$ & $\mathbf{V}_{\mathbf{3}}$ \\
\hline \multicolumn{5}{|c|}{ Reasoning } \\
\hline 1 & Evaluating the validity of the data & 4 & 4 & 3 \\
\hline 2 & Interpret experimental results & 4 & 3 & 3 \\
\hline \multicolumn{5}{|c|}{ Hypothesis testing } \\
\hline 1 & Interpret the relationship between variables. & 3 & 4 & 3 \\
\hline 2 & Knowing the need for more information in making conclusions. & 3 & 4 & 4 \\
\hline \multicolumn{5}{|c|}{ Argument analysis } \\
\hline 1 & Identify important parts of the argument & 4 & 3 & 4 \\
\hline 2 & Summarize the appropriate statement from the data obtained & 4 & 4 & 4 \\
\hline \multicolumn{5}{|c|}{ Likelihood and uncertainty analysis } \\
\hline 1 & Use possible judgments to make decisions & 3 & 3 & 4 \\
\hline 2 & Understand the information that may be in decision making & 3 & 4 & 3 \\
\hline \multicolumn{5}{|c|}{ Problem solving and decision-making } \\
\hline 1 & Identify the best alternative in problem solving & 4 & 3 & 4 \\
\hline 2 & Evaluating the solution to a problem and making decisions based on evidence or facts & 3 & 3 & 4 \\
\hline
\end{tabular}

Table 7. Average Value from Experts and Percentage of Agreement every Aspects

\begin{tabular}{|l|l|l|}
\hline Aspect by Indicator & Avg. value & Percentage of Agreement (\%) \\
\hline Format & 3.56 & 88.89 \\
\hline Language & 3.57 & 85.71 \\
\hline Content & 3.57 & 85.71 \\
\hline Critical Thinking Skill & 3.53 & 93.33 \\
\hline Total & $\mathbf{3 . 5 6}$ & $\mathbf{8 8 . 4 1}$ \\
\hline
\end{tabular}

Based on the data in table 5 and table 6 , the percentage of agreement (PA) for the format, language and content indicators aspects was $88.89 \% ; 85.71 \%$; $85.71 \%$ while the critical thinking indicator got a percentage of agreement of $93.33 \%$ so that the overall percentage of agreement for Dynamic Electricity Worksheets based on Virtual Laboratories was 88.41\% (Table 7). This means that the reliability coefficient / percentage of agreement is above the lower limit (Linn, 2020). So, it can be categorized as good performance. Meanwhile, the average score for the indicators of format, language, content, and critical thinking indicators was 3.56, 3.57, 3.57, and 3.53, respectively. The total score for the virtual laboratory-based Dynamic Electricity Worksheets is 3.56 which means it is in the "Valid" category (can be used with minor revisions). The suggestions / input obtained by the research team from expert validators can be summarized in table 8 :

Table 8. The initial state of dynamic electrical worksheets based on virtual laboratories Expert validators advice and final condition

\begin{tabular}{|l|l|}
\hline Initial Condition & Final Condition \\
\hline $\begin{array}{l}\text { There is no information link about Java or PhET } \\
\text { that should be used by worksheet users }\end{array}$ & $\begin{array}{l}\text { an explanation of the Java and PhET links is given so that the } \\
\text { user knows the application used is appropriate and the same } \\
\text { as what the worksheet maker wants }\end{array}$ \\
\hline $\begin{array}{l}\text { There are no introductions at the beginning of } \\
\text { the Dynamic Electricity Worksheets material }\end{array}$ & $\begin{array}{l}\text { given a foreword / a little introduction about the material that } \\
\text { the students will try out through the Dynamic Electricity }\end{array}$ \\
\hline
\end{tabular}


Validity of Student Worksheet in Chapter Dynamic Electricity Based on Virtual Laboratory

\begin{tabular}{|l|l|}
\hline Initial Condition & Final Condition \\
\hline $\begin{array}{l}\text { There is no instruction sheet for the use of } \\
\text { dynamic electric worksheets }\end{array}$ & $\begin{array}{l}\text { Worksheets } \\
\text { easier for teachers and students }\end{array}$ \\
\hline $\begin{array}{l}\text { The space for pasting the screenshot is quite } \\
\text { narrow }\end{array}$ & $\begin{array}{l}\text { enlarge the space for students to paste the results of the } \\
\text { screenshots in activity } 1\end{array}$ \\
\hline There are already contextual examples & $\begin{array}{l}\text { Very good at activity 2 there is real life NB. "NB" can be } \\
\text { replaced with "Note", and the part is neatly packaged in a } \\
\text { shape format and decorated. this is an emphasis on students } \\
\text { so that it is made striking so that it becomes a concern }\end{array}$ \\
\hline initial writing "pararel" & "Pararel" writing $\rightarrow$ "Parallel" (Standard) \\
\hline $\begin{array}{l}\text { There has been no detailed strengthening in } \\
\text { activity 5. }\end{array}$ & $\begin{array}{l}\text { In activity 5, provide reinforcement until the discovery of how } \\
\text { to calculate grid arranged in series and resistance arranged in } \\
\text { parallel }\end{array}$ \\
\hline
\end{tabular}

After analysing the student worksheet based on expert assessment, the next step is testing the originality of the work through the Turnitin test to find out the plagiarism level of the worksheet. Figure 2 show that the results of the plagiarism check of Worksheet Dynamic Electricity based on Virtual Laboratory with Turnitin. Based on the results of the Turnitin test in Figure 2, it can be stated that the level of plagiarism for the dynamic electricity worksheets based on virtual laboratories is very low, only $5 \%$. Similarity index of $5 \%$ consists of internet sources that are accidentally copied and detected by Turnitin servers. Based on table 4 , the penalty scheme for different similarity indexes shows that the level of plagiarism is included in the parameter category of Similarity index (Si) for no penalty (NP). This shows that in addition to the virtual laboratory-based Dynamic Electricity Worksheets which are categorized as valid and can be used with minor revisions, the originality of this work is also very high.

The following is the sample of layout the virtual laboratory-based Dynamic Electricity Worksheet that has been developed by the research team:

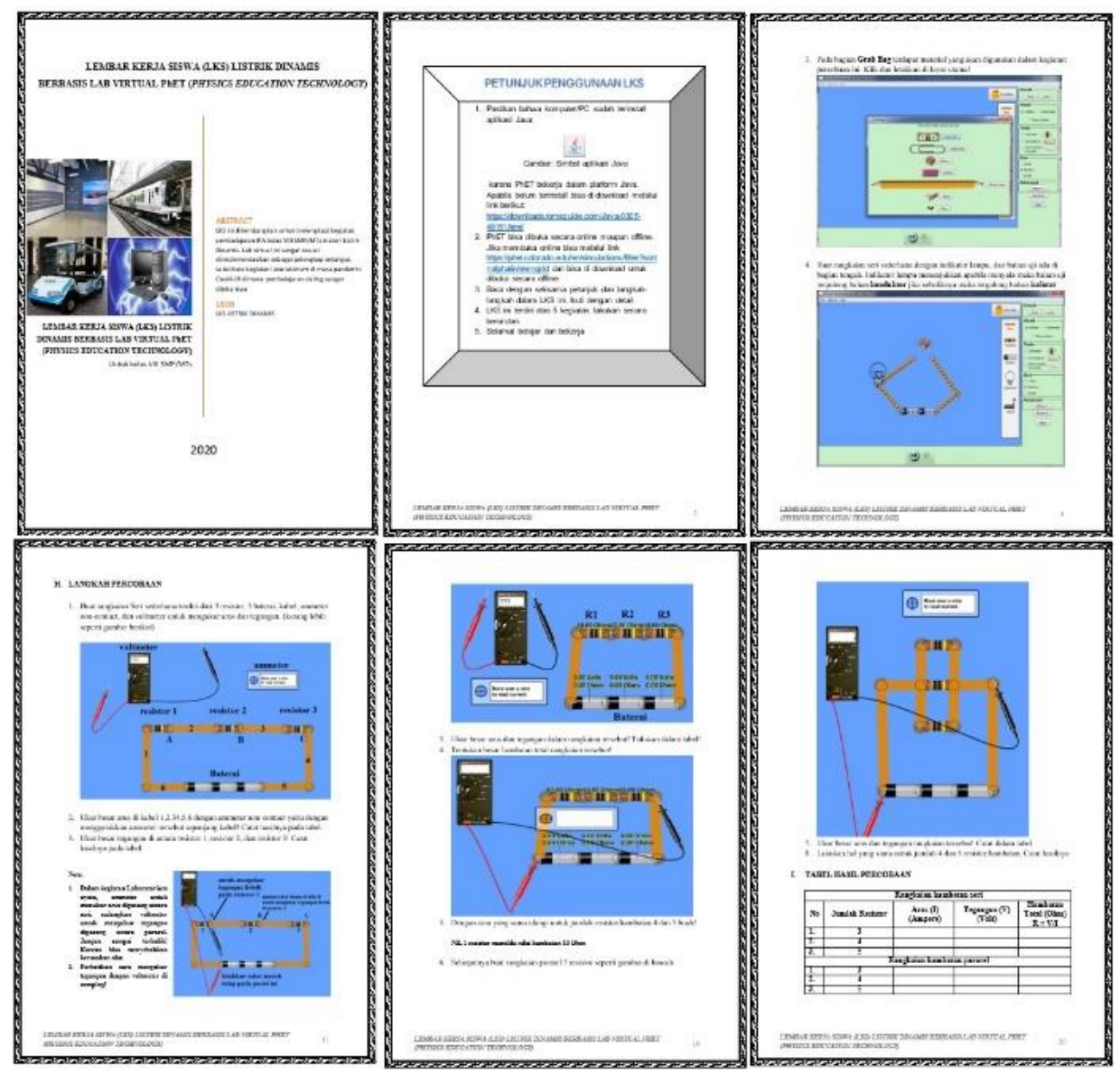

Figure 2. The Sample of Layout Worksheet 


\section{Validity of Student Worksheet in Chapter Dynamic Electricity Based on Virtual Laboratory}

Draft final of Student Worksheet consists of cover, table of contents, instructions for using worksheets, five activities through a virtual laboratory for dynamic electricity materials for junior high school to enhance critical thinking skills and include all 22 pages. All of the activities using virtual laboratory PhET. The $1^{\text {st }}$ activity about Investigation of conductor and insulator materials, $2^{\text {nd }}$ activity about Evaluation of Series Electrical Circuit Characteristics, $3^{\text {rd }}$ activity about Evaluation of Parallel Circuit Characteristics, $4^{\text {th }}$ activity about Comparing Series and Parallel Circuits, and $5^{\text {th }}$ activity or the last one about Analyse the resistance in series and parallel resistance circuits (Moro, 2013), (Nisa, 2018), (Hendri, 2020).

\section{CONCLUSIONS}

Based on the results of the research and discussion previously described, it can be concluded that the student worksheet in chapter dynamic electricity based on virtual laboratory that were developed to improve the critical thinking skills of junior high school students as a companion to online science learning are categorized as valid and can be used with minor revisions. This worksheet also can be categorized good performance based on high reliability/percentage of agreement. The level of originality of the work of dynamic electricity worksheets produced is very high and is in the category of Similarity index (Si) for no penalty (NP). Henceforth, development research can be continued to make critical thinking skills assessment instruments so that the expected improvement can be tested statistically.

\section{ACKNOWLEDGMENT}

Thanks, are given to the Ministry of Education and Culture of the Republic of Indonesia for providing research grants for novice lecturers to the research team. Not forgetting to the Rector of the Lamongan Islamic University through the head of the research and community service institute who gave the team the opportunity to conduct research. Thank you also to the Dean of the Teacher Training and Education Faculty.

\section{REFERENCES}

1) Athaillah, Ibn Khaldun, Mursal. (2017). Improved Understanding of Student Concepts through Virtual Laboratories on Dynamic Electrical Material at SMA Negeri 1 Sukamakmur Aceh Besar. Indonesian Journal of Science Education, Vol. 05, No.01, pp. 114-119, 2017

2) Barry, C. \& Gerstman, J. (2015). Testing the potential for improving student mastery of complex financial concepts online. International Journal of Technologies in Learning.

3) Cicyn, Riantoni \& Astalini, Astalini \& Darmaji, Darmaji. (2019). Study of the use of PhET Interactive Simulations in physics learning. Journal of Research and Physical Education Studies. 6.11.10.2928 / jrkpf.v6i2.14202.

4) Fencl, J. (2013). Using PhET Simulations in the Physics First Classroom: An Alternative to Traditional Laboratories and Teaching Style. Master Paper of Science in Education-Physic. University of Wisconsin River Falls.

5) Finkelstein, N., W. adams, C. Keller, K. Perkins \& C. Wieman. (2006). HighTeach Tool for Teaching Physich: the Physics Education Technology Project.

6) Habibbulloh M. (2019). Effectiveness of The Guided Discovery Model Based Virtual Lab PhET Toward Mastery Students' Concept on Topic Photoelectric Effect. Science Education and Application Journal 1 (1), 1-9

7) Halgamuge, Malka. (2017). the use and analysis of anti-plagiarism software: Turnitin tool for formative assessment and feedback. Computer Applications in Engineering Education. 10.1002/cae.21842.

8) Halpern, D. F. (2014). Thought and knowledge: an introduction to critical thinking (5th Ed.). New York, NY: Psychology Press.

9) Hayes, John \& Hatch, Jill. (1999). Issues in Measuring Reliability: Correlation Versus Percentage of Agreement. Written Communication - WRIT COMMUN. 16. 354-367.10.1177/0741088399016003004.

10) Hendri, Silviana \& Faradhillah, Faradhillah. (2020). Pengembangan LKS Inkuiri Materi Listrik Dinamis. IJIS Edu: Indonesian Journal of Integrated Science Education. 2. 1. 10.29300/ijisedu.v2i1.2670.

11) Ibrahim, Muslim. (2005). Continuous Assessment. Surabaya: Unipress, State University of Surabaya

12) Khairunnisak. (2018). Improved Concept Understanding and Student Motivation through Physic Education Technology (PhET) Simulation. Journal of Science Education Research (JPPIPA) P-ISSN: 2460-2582 | E-ISSN: 2407-795X.

13) Lewin, Lewis \& Wakefield, James. (1979). Percentage agreement and phi: A conversion table. Journal of applied behavior analysis. 12. 299-301. 10.1901/jaba.1979.12-299.

14) Li, Jinrong \& Li, Mimi. (2018). Turnitin and peer review in ESL academic writing classrooms. Language, Learning and Technology. 


\section{Validity of Student Worksheet in Chapter Dynamic Electricity Based on Virtual Laboratory}

15) Linn, Robert. (2020). Educational measurement (3rd ed.). The American Council on Education/Macmillan series on higher education.

16) Martin, Florence \& Polly, Drew \& Ritzhaupt, Albert. (2020). Bichronous Online Learning: Blending Asynchronous and Synchronous Online Learning. MERLOT Journal of Online Learning and Teaching.

17) Moro, Christian \& Kinash, Shelley. (2013). Developing online worksheets that work. Education Technology Solutions Edition: 52Chapter: 1Publisher: Australian Media Group Editors: John Bigelow

18) Nisa, E. K., Koestiari, T., Habibbulloh, M., \& Jatmiko, B. (2018). Effectiveness of guided inquiry learning model to improve students' critical thinking skills at senior high school. Journal of Physics: Conference Series, 997(1).

19) Ratumanan, G.T. \& Laurens, T. (2011). Learning Outcomes Assessment in Education Unit Level. Surabaya: Unipress, State University of Surabaya.

20) Rhim, Hye Chang \& Han, Heeyoung. (2020). Teaching online: foundational concepts of online learning and practical guidelines. Korean Journal of Medical Education. 32. 175-183.

21) Sinaga, Steven. (2018). Use of the Turnitin Application as a Means to Check Plagiarism in the Ukrida University Library Service. BIBLIOTIKA: Journal of Library and Information Studies. 2. 123-131. 10.17977 / um008v2i22018p123.

22) Sugiyono. (2011). Using PhET and Simple KIT for Senior High Schools Subject of Optical Tools to Improve Process and Cooperative Learning Skills. Thesis. Surabaya: Graduate School of Surabaya State University

23) Thiagarajan S, Semmel DS, dan Semmel MI. (1974). Instructional Development for Training Teachers of Exceptional Children. Indiana: Indiana University Bloomington.

24) Tiruneh, Dawit Tibebu \& De Cock, Mieke \& G. Weldeslassie, Ataklti \& Elen, Jan \& Janssen, Rianne. (2016). Measuring Critical Thinking in Physics: Development and Validation of a Critical Thinking Test in Electricity and Magnetism. International Journal of Science and Mathematics Education. 15. 10.1007/s10763-016-9723-0.

25) Villar-Mayuntupa, Gustavo. (2020). Using Turnitin to boost the originality in the elaboration of argumentative essays among Peruvian university students.1-4.10.1109/EDUNINE48860.2020.9149492. 